\title{
THE ANALYSIS OF THE FINDINGS REPORTED IN THE PERFORMANCE AUDIT OF STATE UNIVERSITIES
}

\author{
Durdane KÜÇÜKAYCAN ${ }^{1}$
}

\author{
Şafak AĞDENiZ²
}

\begin{abstract}
With the Public Financial Management and Control Law, the public financial management and control system has been changed within the framework of a new understanding. This new systemis built on the concepts of efficiency, effectiveness, economy, transparency and accountability. One of the innovation that this new public financial management systems is the Performance Based Budgeting system. The basic tools of this system are the annual report, strategic plan and performance report. Performance audit is both an integral part of the performance-based budgeting system and an important tool to guide this system.

Performance audits of state agencies under the general management in Turkey is carried out by the Turkish Court of Accounts(TCA). The TCA fulfills the performance audit task by evaluating the quality of performance information in the basic tools of the performance-based monitoring process of public administrations. Public universities with special budgets, which are one of the public administrations within the scope of general government, are also subject to the performance audit of the TCA. The public is assured about the accuracy and reliability of non-financial performance information, which is based on the service delivery of the universities by the performance audit conducted by the TCA. The performance audit of the TCA is an integral part of both the guiding and budgeting process in terms of showing the improper practices of universities in the performancebased budgeting process and providing suggestions for correcting them.

This study aims to research the results of a performance audit of the state universities conducted by TCA For this purpose, the results of the performance audits of 38 universities, which were conducted in 2017, were examined using content analysis. As a result of the analysis, it has been determined that there are universities that do not meet both the reporting requirements and the criteria for the content of performance information.
\end{abstract}

Keywords:.Audit, Performance Audit, Court of Accounts, Universities.

JEL Code: H83, H89.

\section{Introduction}

Performance audit is an effective tool for controlling the effective, efficient and economical availability of public resources. Published performance audit reports play an important role in recognizing the existing shortcomings, making decisions for the future and informing the taxpayers. Therefore, analyzing the findings in the performance audit reports is an important issue in terms of public financial management.

Performance audits of public institutions in Turkey are carried out by the TCA and internal audit units. In this study, the performance audit results performed by the TCA were analyzed. A reason for analyzing the TCA audit reports is that these reports are open to the public and another

\footnotetext{
1 Dr., Eskişehir Osmangazi University, Faculty of Economics and Administrative Sciences, Department of Public Finance, Budget and Fiscal Planning, durdane@ogu.edu.tr

2 Dr., Eskişehir Osmangazi University, Faculty of Economics and Administrative Sciences, Department of Management, Accounting and Finance, agdenizsafak@gmail.com
} 
reason is that, as stated by Akyel (2016: 120), the findings and determinations, evaluations and suggestions included in these reports are closely monitored by related institutions and stakeholders, as well as by the community regarding the academic and auditing profession.

In the light of this information, the scope of the study was determined as an analysis of the findings reported in the performance audits conducted by TCA of 102 universities in the ranking of URAP (University Ranking by Academic Performance) in 2018. The main purpose of the study is to examine the performance audit reports of the universities which have performance audits in terms of performance audit criteria. In this study, performance audit reports will be analyzed by using content analysis and the findings of the audit reports will be discussed.

\section{Audit and Audit Types}

The concept of audit is based on the verb "audire" which means is hearing or listening" in Latin (Bozkurt, 2015:23). The audit phenomenon, which is an indispensable element of management, is also an important tool for the modern organization understanding (Çevik, 2002:105).One of the definition in the literature related to the audit is given below:

The audit is an activity carried out in order to ensure compliance with the standards, predetermined objectives and aims, rules and regulations related to the subject, to determine the contradictions and to make suggestions regarding the necessary actions(Candan, 2007:7).

Ensuring efficiency in resource allocation and improving the performance of management are two main functions of the audit. Several types of audits are used to achieve these two objectives. There are various types of audits classified in various aspects.

\subsection{Performance Audit}

Over time the growth and complexity of the state activities caused the control of the public to change and develop,thus the area of audit evolved from financial audit or conformity audit, also known as traditional auditing that was reigned for many years to performance audit (Demirbaş \& Engin, 2016: 29). Performance audit emerged in the 1940s with the importance of process control to measure the productivity of firms according to industry standards (Kubalı, 1998: 12).

The most accepted definition in the literature on performance audit was made by the International Organization of Supreme Audit Institutions (INTOSAI). INTOSAI defines the performance audit as follows (INTOSAI, 2016: 7):

"It relates to the audit of economy, efficiency and effectiveness and includes the following:

- Auditing of the economy of administrative activities according to the principles and practices and management policies,

- Auditing of efficiency in the use of human, financial and other resources, including information systems, performance measures and surveillance regulations, and review of methods to address deficiencies identified by the audited bodies;

- Auditing the effectiveness of the performance of the audited organizations in achieving their objectives and comparing the actual impact created by the corporate activities with the intended effect. 
In the definition of performance audit given above, efficiency, effectiveness and economy are defined as performance evaluation components. These performance evaluationcomponents are shown in Figure 1.

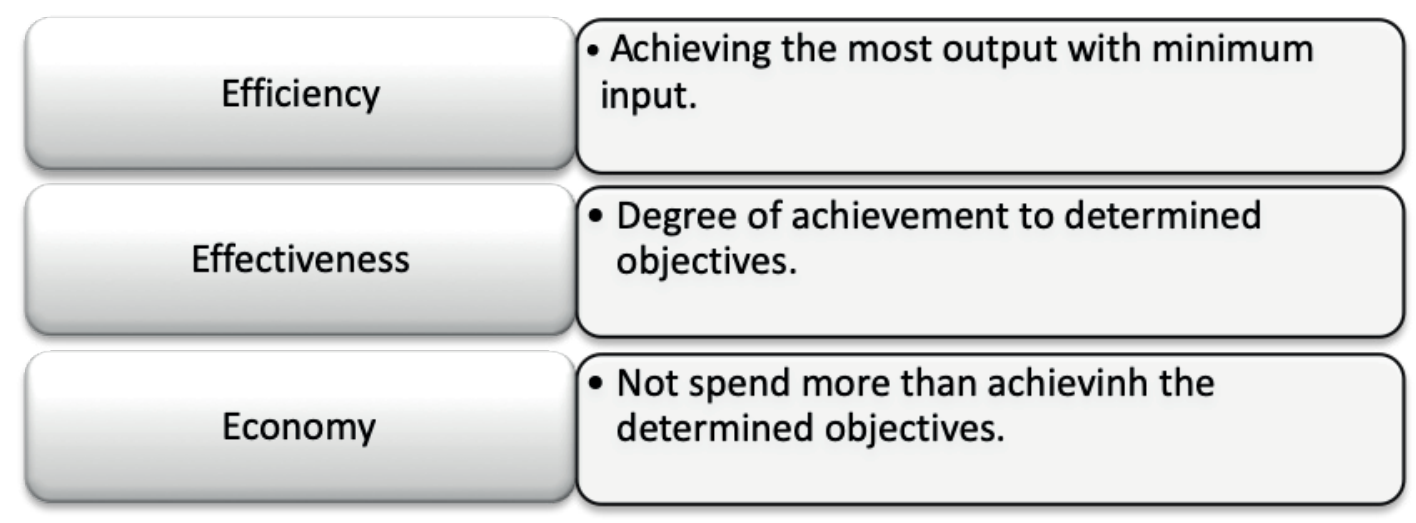

Figure 1. Components of Performance Audit

These three criteria given in Figure 1 are internationally accepted and most widely used performance audit components.

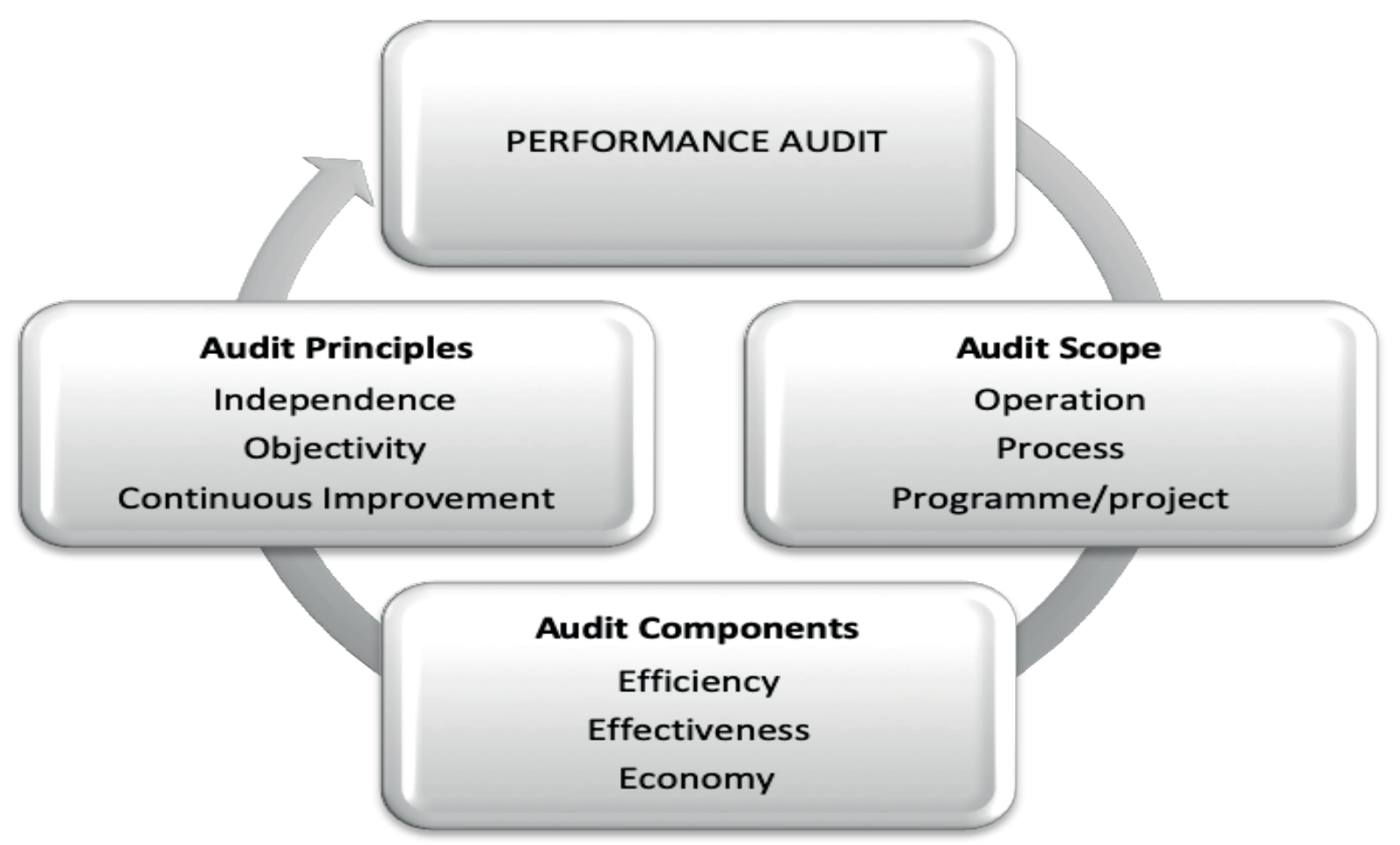

Figure 2. Performance Audit 
The general features of the performance audit schematized in Figure 2 can be listed as follows (Demirbaş, 2001: 64-66):

- An organization, program, activity or service can be audited partially or fully through performance audit.

- Performance audits do not result in a judicial decision.

- Performance audit using financial and non-financial data requires interdisciplinary work.

- The scope of the performance audit is wide.

- Performance audit is a type of audit that is complex, time-consuming, requires intensive operations and beneficial compared to cost.

The main function of performance audit is to lead and guide the institutions and managers for the future (Akyel \& Köse, 2010: 20).

\subsection{Perfomance Audit Practices in Turkey}

The introduction of performance audit to Turkish Public Administration literature was in 1996 with international initiatives. However, the performance audit was put into legal infrastructure and the resulting gaps were filled with Law No. 6085 prepared in line with Law No. 5018 (Önder \& Türkoğlu, 2012: 201).

According to Edizdoğan and Çetinkaya (2016: 361) 5018 numbered Public Finace Management and Control Law (PFMC) and 6085 numbered Law on the Court of Accounts, the financial control and supervision in our country is given below.

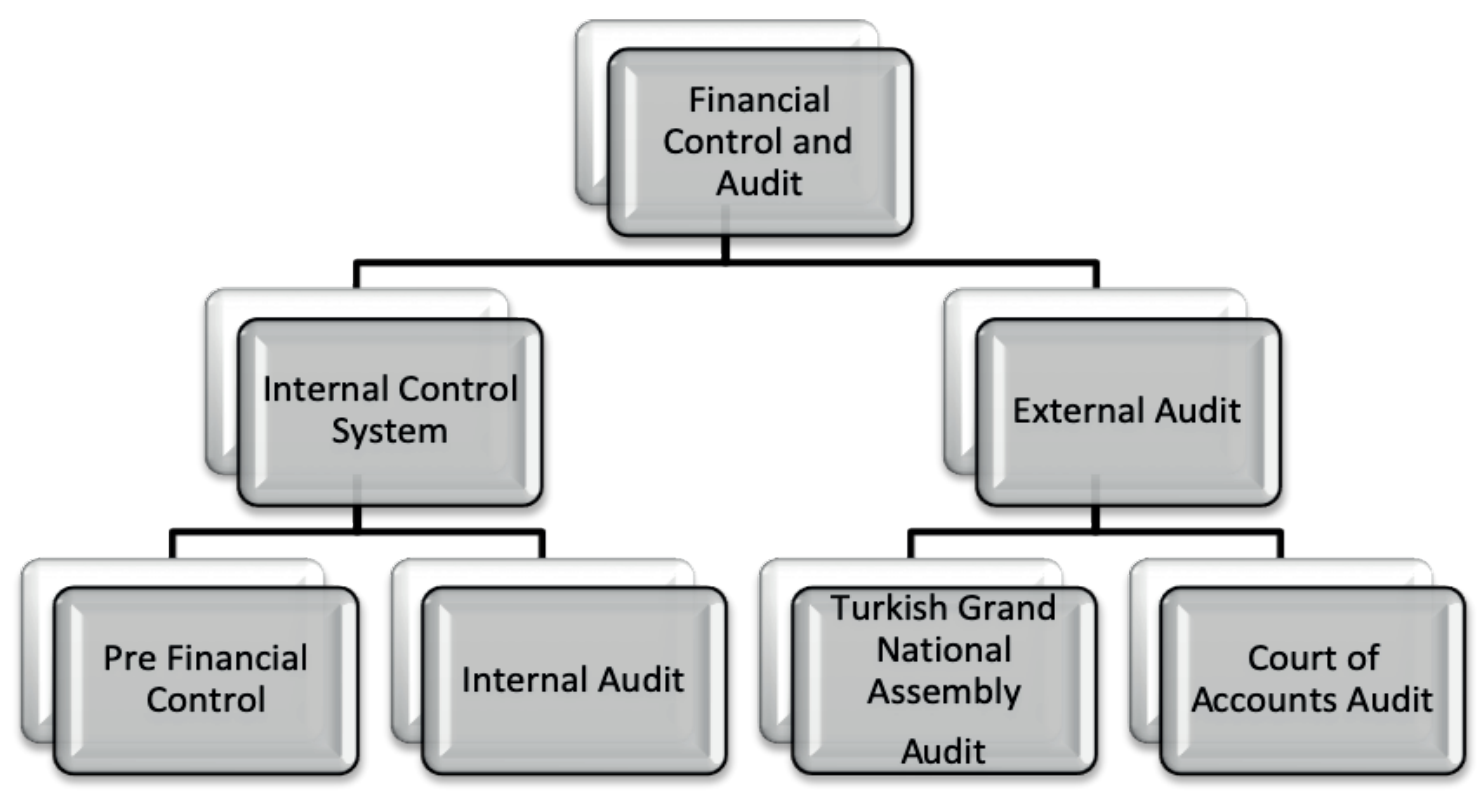

Figure 3. Financial Control and Audit in Turkey 
These two Laws, where the foundations of performance audit were laid, were assigned with two bodies to carry out the audit. These:

- Internal audit units in the context of the internal control system of public institutions,

- The Court of Auditors for the external audit of public institutions.

As performance audit reports were analyzed in the study, the performance audit performed by TCA was discussed in the following section.

\subsection{The Court of Accounts and Performance Audit}

TCA, which has institutional and functional independence, plays an important role in the development of public administration in accordance with the principles of accountability and transparency and in the use of public resources in accordance with the law, objectives and principles of good governance(Akyel, 2016: 120). Article 36 of the Law on the Court of Accounts No. 6085 entered into force in 2010 and the task of evaluating the plans and programs prepared by the administrations (in the context of objectives and objectives, activities and performance targets) was given to TCA with the power of performance auditing. The audit tasks to be carried out by TCA pursuant to the Law article shall include:

- Regularity audit,

- Financial audit

- Compliance audit

- Performance audit.

In the "Performance Audit Guide" published by TCA in order to guide the practitioners, the Court of Accounts has three main objectives in performing the performance audit (Sayıştay, 2014: 6):

- In order to ensure accountability and transparency in public financial management, public administrations should provide performance information in accordance with Law No. 5018.,

- Contribute to the usefulness and quality of the reported information,

- To inform the Turkish Grand National Assembly and the public about the accuracy of the information contained in the activity reports prepared by the public administrations to monitor and report the progress they have made in terms of performance targets and indicators.

Again, in this guidance, the criteria to be used to perform the performance audit of TCA and the definitions of these criteria (what they mean) are given in Table 1. 
Table 1. Performance Audit Criterias

\begin{tabular}{|l|l|}
\hline Performance Audit Criterias \\
\hline Audit Criteria & Definition \\
\hline Existence & $\begin{array}{l}\text { The supervised administration shall prepare relevant documents according to } \\
\text { the legal regulations. }\end{array}$ \\
\hline Timeliness & Reporting of performance information within the legal period \\
\hline Presentation & $\begin{array}{l}\text { Reporting performance information in accordance with the regulatory } \\
\text { principles }\end{array}$ \\
\hline Relevance & Logical link between goal, objective, indicator and activities \\
\hline Measurability & Measurable targets or indicators \\
\hline Well defined & Have a clear definition of targets and indicators \\
\hline Consistency & $\begin{array}{l}\text { Consistent use of targets (including indicators) in the planning and reporting } \\
\text { documents of the supervised administration }\end{array}$ \\
\hline Verifiability & Repored performance information can be traced to the source \\
\hline Validity & $\begin{array}{l}\text { Any deviation between planned and reported performance is addressed by the } \\
\text { audited entity and the reasons for the deviation are convincing and convincing. }\end{array}$ \\
\hline Reliability & $\begin{array}{l}\text { To be able to provide reliable data in the annual report by accurately and } \\
\text { accurately measuring the realizations of data recording systems. }\end{array}$ \\
\hline
\end{tabular}

Source: Sayıştay Başkanlığı, 2014: 7

The performance reports discussed in this study were evaluated according to the criteria given in Table 1.

\section{Research Approach}

\subsection{Sample Selection}

The performance audit carried out by TCA includes all public universities. However, performance audits are not performed in all universities.Therefore, universities not performing performance audits by TCA were excluded from the study.It was determined that TCA carried out performance audit of 38 universities.The audit reports of all universities that were audited were examined and no sampling was performed.

\subsection{Methodology}

Content analysis is used as a qualitative method in the study. It is considered that content analysis is the most appropriate method for evaluating the results of the performance audit report.In this study, meeting/not meeting criteria that are included in the performance audit reports of the universities (criteria given in Table 1) were analyzed. Summary, general evaluation and findings section of the performance audit reports were evaluated. The information in the reports was examined and evaluated by content analysis in which performance audit criteria were fulfilled. 


\subsection{Findings}

According to the results of 2017 performance audit, 7 university strategic plans, 1 university performance program and 6 university annual reports were not published on time in accordance with the legislation.

23 findings related to the presentation criteria of all three documents belong to the strategic plan, 17 findings belong to performance programs and 17 findings belong to annual report. The most common error forthe strategic plan are over goal setting and partial/completely includes of basic tables (T1-T5) for performance programme. While the most coomon error for the annual report is not including the reasons for the deviations from the performance targets.

There are 21 findings about the content of the performance information criterias (relevance, measurability and well defined) of all three documents.There is a link between the strategic plan, the performance report and the annual report in the evaluation of the criterias in performance audit.For example, when the strategic plan is audited, the audit team cannot make any evaluation regarding the performance target and indicator of this target in the performance program if it is determined that the objectives in the plan are irrelevant to the objectives. For the unrelated objectives in the strategic plan, the performance program does not assess the criteria for relevance, measurability and well defined. Also, there is no evaluation for the content of performance information for universities that do not meet the timeliness criteria. Therefore, there is little evidence for the content of performance information.

When the results of the audit regarding the measurement and evaluation of the operating results are examined, it is seen that the data recording system of 11 universities has not been established regarding the existence of data recording system.Also, while out of the scope of this study, nonstandard performance audit report were seen.

\section{Conclusion}

In this study, the results of the performance audits of 38 of the 102 universities in the URAP ranking in 2018, which were conducted in 2017, were examined using content analysis.TCA evaluated the quality of performance information in the performance-based budgeting process of universities by performance audit. Therefore, the poor orquality of information in the documents of the universities are explained to the public through performance audit reports. The findings whetherthe universities are fulfilled the performance audit criteria is determined. As a result of the analysis, it has been determined that there are universities that do not meet both the reporting requirements and the criteria for the content of performance information.

Performance audit criteria provide guidance on how to make an accurate reporting of universities. It was observed that the performance audit of the TCA is guiding for performance-based budgeting process of universities.Therefore, it is important to increase the number of universities with performance audits. Performance audit does not cause financial and legal responsibility for university administrators. It is not mean that university administrators not be free of accountability. The increase in the number of public universities in our country increased the share of public resources. Therefore, it has necessitated for university administratorspublic resources use withefficiency, effectiveness, economy. 


\section{References}

Akyel, R. \& Köse, H. Ö. (2010). “Kamu Yönetiminde Etkinlik Arayışı: Etkin Kamu Yönetimi için Etkin Denetimin Gerekliliği", Türk İdare Dergisi, 466(Mart), 9-45.

Akyel, R. (2016). "Sayıştay Raporlarının Kamu Mali Yönetimine Katkısı", Amme İdaresi Dergisi, 49(1), 119-145.

Bozkurt, N. (2015). Muhasebe Denetimi, 7.Baskı, Alfa: İstanbul.

Candan, E.(2007). Türk Bütçe Sisteminde Performans Denetimi, T.C. Maliye Bakanlığı, Strateji Geliştirme Başkanlığı.

Çevik, S. (2002). "Türk Bütçe Sisteminde Denetim:Geleneksel Denetimden Performans Denetimine”, Selçuk Üniversitesi Hukuk Fakültesi Dergisi, 10(1-2), 104-129.

Demirbaş, T. (2001). "Sayıştaylar Tarafindan Gerçekleştirilen Performans Denetimleri ve Türk Sayıştayı Uygulaması”, TC Sayıştay Başkanlığı Araştırma/Inceleme/Çeviri Dizisi:17.

Demirbaş, T. \& Engin, R. (2016). “Sayıştayın Belediyeler Üzerindeki Performans Denetimlerinde Ulaşthğı Bulguların Analizi”, Sayıştay Dergisi, 100, 27-60.

Kubalı, D. (1998). "Performans Denetimi Kavram Ilkeler, Metodoloji ve Uygulamalar". TC Sayıştay Başkanlığı Cumhuriyetin 75.Yıldönümü Dizisi:11.

Türk Dil Kurumu. Güncel Türkçe Sözlük, http://www.tdk.gov.tr/index.php?option=com_ gts\&arama=gts\&guid=TDK.GTS.5c6154174f37d9.55411066, Erişim Tarihi: 11.02.2019.

T.C. Sayıştay Başkanlığı (2014). “Performans Denetimi Rehberi”, Aralık, Ankara.

Önder, Ö. \& Türkoğlu, İ. (2012). Denetim Anlayışının Değişimi: Yeni Sayıştay Kanunu Üzerine Değerlendirmeler. Uluslararası Yönetim İktisat ve İşletme Dergisi, 8(17), s. 197-214.

6085 Sayılı Sayıştay Kanunu, 19.12.2010 Tarihli, 27790 Sayılı Resmi Gazete. 